\title{
CRISPR Screening: Molecular Tools for Studying Virus-Host Interactions
}

\author{
Vladimir Chulanov 1,2,3 ${ }^{D}$, Anastasiya Kostyusheva ${ }^{1}$, Sergey Brezgin ${ }^{1,2} \mathbb{D}$, Natalia Ponomareva ${ }^{1,4}$, \\ Vladimir Gegechkori ${ }^{4}\left(\mathbb{D}\right.$, Elena Volchkova ${ }^{3}$, Nikolay Pimenov ${ }^{1}$ (D) and Dmitry Kostyushev ${ }^{1,2,3, *(\mathbb{D})}$
}

1 National Medical Research Center of Tuberculosis and Infectious Diseases, Ministry of Health, 127994 Moscow, Russia; vladimir@chulanov.ru (V.C.); kostyusheva_ap@mail.ru (A.K.); seegez@mail.ru (S.B.); ponomareva.n.i13@yandex.ru (N.P.); n.pimenov@mail.ru (N.P.)

2 Scientific Center for Genetics and Life Sciences, Division of Biotechnology, Sirius University of Science and Technology, 354340 Sochi, Russia

3 Department of Infectious Diseases, Sechenov University, 119991 Moscow, Russia; az@rcvh.ru

4 Department of Pharmaceutical and Toxicological Chemistry, Sechenov University, 119991 Moscow, Russia; vgegechkori@gmail.com

* Correspondence: dkostushev@gmail.com

\section{check for}

updates

Citation: Chulanov, V.;

Kostyusheva, A.; Brezgin, S.;

Ponomareva, N.; Gegechkori, V.;

Volchkova, E.; Pimenov, N.;

Kostyushev, D. CRISPR Screening:

Molecular Tools for Studying

Virus-Host Interactions. Viruses 2021,

13, 2258. https://doi.org/10.3390/

v13112258

Academic Editors: Jiri Hejnar and Ben Berkhout

Received: 13 October 2021

Accepted: 9 November 2021

Published: 11 November 2021

Publisher's Note: MDPI stays neutral with regard to jurisdictional claims in published maps and institutional affiliations.

Copyright: (c) 2021 by the authors. Licensee MDPI, Basel, Switzerland. This article is an open access article distributed under the terms and conditions of the Creative Commons Attribution (CC BY) license (https:// creativecommons.org/licenses/by/ $4.0 /)$.

\begin{abstract}
CRISPR/Cas is a powerful tool for studying the role of genes in viral infections. The invention of CRISPR screening technologies has made it possible to untangle complex interactions between the host and viral agents. Moreover, whole-genome and pathway-specific CRISPR screens have facilitated identification of novel drug candidates for treating viral infections. In this review, we highlight recent developments in the fields of CRISPR/Cas with a focus on the use of CRISPR screens for studying viral infections and identifying new candidate genes to aid development of antivirals.
\end{abstract}

Keywords: SARS-CoV-2; COVID-19; hepatitis; HIV; Cas12; Cas9; HAV; ZIKV

\section{Introduction}

Viruses are obligate pathogens that use the host-cell machinery for replication. Host cells can recognize the virus and activate antiviral responses. Revealing the factors that affect viral infection can aid in discovery of new drug candidates. Using specific immune agonists that contribute to antiviral immune responses is another approach for treating infections. Studying host-cell interactions and identifying critical targets for developing new antivirals have recently become possible using new, comprehensive molecular tools such as clustered regularly interspaced short palindromic repeats (CRISPR) screens. Over the last decade, CRISPR/CRISPR-associated protein (Cas) systems have been adopted for genome editing. Cas proteins recognize the target site using single-guide RNA (sgRNA) in type II CRISPR systems and CRISPR RNA (crRNA) in type V systems (for simplicity, named gRNA in this review) only if the genomic target is followed by a protospacer adjacent motif (PAM) sequence (NGG for Cas9 protein and TTTV for Cas12a protein). Upon target site recognition, Cas proteins unwind the DNA strands, forming an R-loop structure, and cut the two strands, resulting in a DNA double-stranded break (DSB).

Using site-specific mutagenesis, a variant of Cas endonuclease with nucleolytically blunt domains has been generated, known as nucleolytically dead Cas (dCas) protein. dCas retains the ability to bind the site of interest but cannot introduce DSBs into DNA. Fusing different functional domains to dCas proteins transforms them into molecular "Swiss army knives" with a variety of functions, such as single-nucleotide editing and regulating transcription and epigenetics [1]. Activating or inhibiting target gene transcription by different CRISPR/Cas systems has been widely used to disrupt individual genes and study virus-host interactions [2]. By designing and synthesizing thousands of gRNAs targeting multiple genes of interest or all genes in the genome, it is possible to use CRISPR/Cas 
techniques to directly investigate the function of host factors in a large-scale format, referred to as CRISPR screens [3]. Using sets of gRNAs (gRNA libraries), CRISPR screens enable perturbation of thousands of genes simultaneously to evaluate their functions in a single experiment.

CRISPR screens are widely used to investigate complex biological processes, including virus-host interactions, in a high-throughput manner. These cutting-edge molecular tools enable whole-genome analysis of host factors, identifying and validating the effects of these factors on viral replication. This manuscript reviews the basic principles, types, and workflow of CRISPR screens. In the second part of this review, we provide a comprehensive analysis of recent discoveries made using CRISPR screens for investigating virus-host interactions and identifying new antiviral drug targets.

\section{CRISPR/Cas-Based Molecular Tools Used for CRISPR Screens}

Classical Cas9 nucleases (type II CRISPR/Cas systems) recognize a specific target and introduce DNA DSBs, which are then repaired by error-prone cellular mechanisms. Disrupting gene coding sequences by frameshift mutations enables the use of classical Cas9 nucleases for gene knockout applications (CRISPR-ko).

Cas12a enzymes (type V CRISPR/Cas systems) possess RNAse activity, so several gRNAs can be transcribed as a single transcript that is further processed by Cas12a into individual gRNAs [4]. This unique feature of Cas12a facilitates multiplex targeting and makes Cas12a particularly suitable for combinatorial CRISPR screening.

Instead of inactivating two nucleolytic domains, as dCas9 proteins do, leaving a single functional nucleolytic domain repurposes Cas9 from introducing DSBs to nicking a single DNA strand. These modified Cas9 proteins are named Cas9 nickases (nCas9). Fusing dCas9 or nCas9 proteins with different functional domains endows them with new properties. Based on the functional domain used, dCas $9 / \mathrm{nCas} 9$ systems can be adapted for a wide range of biological applications (reviewed in [1]), including:

- $\quad$ DNA base editing (cytidine deaminases APOBEC3A [5], rAPOBEC1 [6], AID [7])

- Gene repression via CRISPR-interference (CRISPRi): dCas9 fused with KRAB [8-10], EZH2 [10], KRAB-MeCP [11], DNMT3A [12], DNMT3L [13]

- $\quad$ DNA methylation or de-methylation (DNMT3A [13,14] or TET1 [15]) for modulating gene expression

- $\quad$ Gene activation via CRISPR activation (CRISPRa) (VPR [16,17], SAM [18], SunTagVP64 [19] and others)

Base editing can be achieved using nCas9 fused with a DNA deaminase domain (APOBEC3A, rAPOBEC1, AID, or their improved variants) [20]. Cytidine base editors mediate deamination of target cytidine nucleotides, resulting in $\mathrm{G} \rightarrow \mathrm{A} / \mathrm{C} \rightarrow \mathrm{T}$ mutations [21], and can be used for DSB-independent gene knockout.

dCas9 protein fused to transcriptional repressors is used for CRISPRi (gene repression). The KRAB domain is a eukaryotic transcriptional repressor commonly used for CRISPRi. dCas9-KRAB systems suppress gene transcription by recruiting epigenome remodeling cellular enzymes that add inhibitory epigenetic modifications to target loci [22]. The disadvantage of dCas9-KRAB inhibitors is variable efficacy, depending on loci and gRNAs, as well as the transient nature of gene inhibition [22]. The combined system dCas9-KRAB-MeCP2 demonstrates higher inhibitory activity than dCas9-KRAB alone, as $\mathrm{MeCP} 2$ attracts additional repressors, thus prolonging the effects of transcriptional inhibition and enhancing efficiency [11]. Adding DNA methyltransferase domains DNMT3A-3L to dCas9-KRAB (DNMT3A-3L-dCas9-KRAB; CRISPR-off) potentiates the inhibitory activity and duration of the epigenetic memory, so that repression of gene transcription persists even after dCas9 systems are released and degraded [23].

To activate genes, $\mathrm{dCas} 9$ has been fused to different activation domains. One of the most powerful activation tools is the three-component complex of transcriptional activators VP64-p65-Rta (VPR) characterized by substantially higher gene activation efficiency than first-generation systems. Another effective activation system is the synergistic activation 
mediators (SAM) system consisting of fused dCas9-VP64 protein and modified gRNA containing two MS2 RNA aptamers [18]. MS2 aptamers in gRNA can recruit up to four copies of aptamer-binding MCP proteins linked to p65-HSF1 activation domains. In the SunTag activation system [12], dCas9 is linked to an array of short GCN4 peptide repeats; VP64 activation domains are coupled to anti-GCN4-scFv fragments. Using antibody-antigen interaction, dCas9-GCN4 mobilizes up to $10 \mathrm{scFv}$-VP64 domains to the regulatory site. Current advances in the CRISPR toolbox have been described in detail elsewhere $[1,24-26]$.

\section{Types of CRISPR Screens}

\subsection{Pooled and Arrayed CRISPR Screens}

Screening protocols can be run in two formats: arrayed screens or pooled screens. Arrayed screens are usually conducted in 96-well plates with 1 gRNA per each well, while in pooled screens, cells are transduced with a gRNA mix. The desired phenotype is selected, and the mutation that caused the desired phenotype is identified using next-generation sequencing (NGS) [27]. CRISPR screens for viral applications are typically performed in pooled format.

\subsection{Loss-of-Function and Gain-of-Function CRISPR Screens}

CRISPR screens can be divided into three categories by mechanism of action: CRISPRi, CRISPRa, and CRISPR knockout screens.

CRISPR-ko and CRISPRi are loss-of-function approaches. CRISPR-ko screens are based on classical CRISPR/Cas9 systems, which result in DSBs and indel mutations, or on cytidine base editors, which convert codons into stop codons, leading to production of truncated, non-functional proteins (CRISPR-STOP or iSTOP approaches) [28,29]. In addition to gene knockouts, CRISPR base editors can be used to screen gene isoforms formed by single-nucleotide mutations in genetic disorders and cancers [30-32]. The main limitation of CRISPR-ko screens is potential arbitrary disruption of genes important for cell viability, which can lead to cell death, loss of sgRNA hits, and misinterpretation of CRISPR-ko screening results. If gene function is not completely disrupted, a truncated protein with altered functions may be produced, also compromising CRISPR-ko results. Cas9-induced DSBs can non-specifically induce genotoxicity, loss of chromosomes, and genome rearrangements, which may undermine the validity of CRISPR-ko screens. In this respect, CRISPR-ko screens using base editors are more reliable, as these enzymes generate low rates of indel mutations and low genotoxicity [33].

In CRISPRi screens, dCas9 is fused to gene repressors (KRAB, KRAB-MeCP2, DNMT3A3L-dCas9-KRAB (CRISPR-off)), which inhibit target gene activity. Unlike CRISPR-ko, CRISPRi markedly suppresses target gene transcription by epigenetic mechanisms, eliminating the risk of producing truncated proteins and genotoxicity. Additionally, RNA interference, the canonical method for loss-of-function screens, results in less efficient gene knock-down and typically has higher rates of non-specific effects than CRISPRi [34,35].

CRISPRa screening is a gain-of-function method using dCas proteins fused to gene activation domains (VPR [16], SunTag [36], SAM [18]) that can endogenously induce target gene expression [37]. CRISPR screens have several advantages over cDNA libraries, which overexpress specific gene isoforms from robust promoters. Gene activation by CRISPRa allows more physiologic gene levels, rather than the vast overexpression seen using cDNA libraries. Every gene can be activated, in contrast to cDNA libraries, in which the size of the gene and impairment of viral vector production may be a challenge. Finally, CRISPR enables robust activation of all or many isoforms of the same gene. However, CRISPRa/CRISPRi can potentially affect bispecific promoters, thus altering expression of off-target genes by a single gRNA. Efficacy of different gRNAs targeting single genes is also highly variable, resulting in bias in pooled CRISPR screens [38,39]. 


\subsection{Classical and Combinatorial CRISPR Screening}

In classical CRISPR screens, thousands of gRNAs are introduced into cells with one gRNA per cell. However, certain situations require testing the effects of a combination of genes in one cell. To investigate potential gene interactions and discover new drug targets, CRISPR screens can be performed in combinatorial format, with several genes altered in a single cell. DeWeirdt et al. optimized Cas12a (previously known as Cpf1) nuclease from Acidaminococcus sp. Cas12a (AsCas12a) for pooled screens [40]. With Cas12a, several gRNAs can be transcribed by RNA polymerase II as a single polyadenylated transcript, then processed by Cas12a into individual gRNAs [41]. The authors validated the optimized AsCas12a system in performing dual or triple knockout screens [40]. Alternately, combinatorial screening (up to three knockouts per cell) can be done using classical Cas9 with barcoded gRNAs. These barcodes are unique for each assembled combination of gRNAs and thus can be analyzed by NGS. All gRNAs are encoded by a single lentiviral vector. This approach is compatible with dCas9-based CRISPR screening systems [42].

\section{Workflow of CRISPR Pooled Screening}

\subsection{Design of gRNAs for CRISPR Screens}

The main steps of a generalized CRISPR screening protocol are provided in Figure 1. The first step in performing a CRISPR screen is designing the gRNA libraries. Several issues must be considered here. First, gRNA efficacy can vary widely [43] depending on nucleotide sequence, preference of cytosine residues [44], melting temperature [45,46], purine content [47], PAM-distal GC content [48], cell model used, and other features. Several bioinformatics algorithms have been developed to predict gRNA efficiency and specificity. Today, algorithms for calculating gRNA efficiency and specificity are integrated into convenient online tools used for different CRISPR applications, including CHOPCHOP [49], E-CRISPR [50], CRISPOR [51], CRISPRscan [47], CCTop [52], GT-scan [53], GuideScan [54], MultiGuideScan [55], CRIPSRDo [56], and Wu-CRISPR [57]. Most web-based tools allow selection of preferable algorithms for on-target and off-target score estimation. Advantages and limitations of CRISPR gRNA design tools have been reviewed previously [58-60].

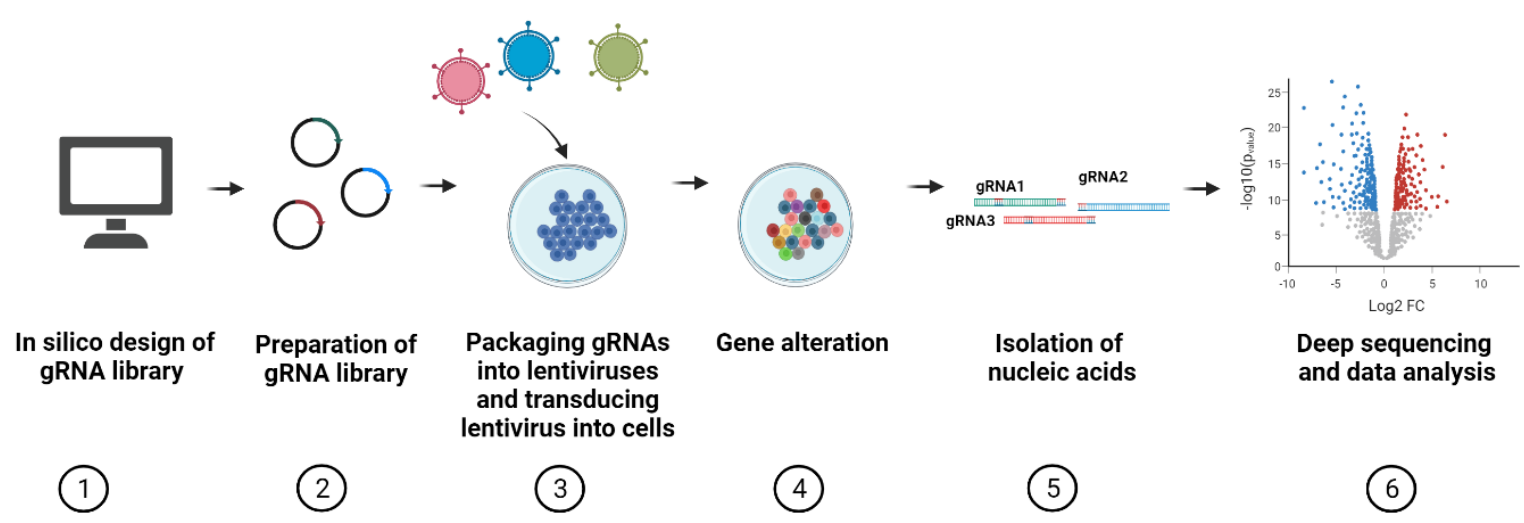

Figure 1. General workflow of CRISPR screens. CRISPR screening protocols include 6 main steps: (1) in silico design of gRNA libraries; (2) cloning and validation of gRNA library; (3) packaging gRNAs into lentiviruses and transduction of lentiviruses into Cas-expressing cells; (4) alteration of genes in experimental conditions; (5) isolation of nucleic acids; and (6) deep sequencing of barcoded gRNAs and data analysis. Note: if using pre-made gRNA libraries, the first two steps of the protocol are omitted.

Epigenetic modification can influence gRNA efficacy. Typically, the most effective gRNAs are located in nucleosome-free sites with open chromatin [60,61]. When designing gRNAs for CRISPRi/CRISPRa, the position of gRNA in the region of the gene transcription start site (TSS) plays a crucial role [43]. Highest gRNA efficacy for CRISPRi is observed for positions located from +50 to +100 nucleotides from the TSS [37], whereas the best window for CRISPRa gRNAs is -150 to -75 nucleotides upstream of the TSS [62,63]. A plethora of 
studies demonstrated the importance of exhaustive in silico gRNA design for generating valid CRISPR screening results. Several online tools also consider epigenetic features of the target site in gRNA design (Wu-CRISPR [57], Azimuth [46], CRISPRpred [64], TSAM [65], uCRISPR [66]).

Designing gRNAs for base editors can be complicated, as additional factors should be considered during selection. The PAM sequence should be located near the target sequence to introduce the desired mutation or create a stop codon. The editing window of most base editors is narrow (usually 13-17 nucleotides from PAM) and depends on the base editor used [21]. For iSTOP technology, a special database was created containing gRNA sequences that enable knockout of $97-99 \%$ of genes in eight eukaryotic organisms. These gRNAs can potentially be used for designing a genome-wide library [28]. gRNAs for custom libraries can be also designed with the convenient web tool BE-Designer, which allows gRNA selection for commonly used base editors [67].

Finally, using one gRNA to target a gene may be insufficient. The common approach is to design at least $4-10$ gRNAs targeting a single gene to obtain consistent results between gRNAs and provide high statistical power [68]. However, as the number of gRNAs in a library increases, the screening approach requires larger numbers of cells and increased depth of NGS coverage [46]. Depending on the investigation's purposes, a library can be designed to alter all genes in the genome (genome-wide format) or to study a single biological pathway.

\subsection{Available sgRNA Libraries for CRISPR Screens}

Pre-made gRNA libraries are publicly available through AddGene. Alternatively, custom sets of gRNAs can be created for different purposes. gRNA libraries can be designed for modulating a specific cellular pathway or the entire genome. Genome-wide libraries provide the most comprehensive screening data but contain a large number of gRNAs (usually $>100,000$ ) and thus require huge numbers of cells and very high sequencing depth to reveal screening hits. The most commonly used genome-wide libraries are GeCKO/GeCKOv2 [69,70], Toronto [71], Brunello (CRISPR-ko) [63], Dolcetto [63], CRISPRi-v2 (CRISPRi) [61], Calabrese [63], Mini-Human [72], Gattinara [73], and CRISPRa-v2 (CRISPRa) [61]. These libraries target over 18,000 genes with 4-10 gRNA per gene. GeCKOv2 contains 1864 gRNA sequences targeting miRNA-encoding sequences involved in transcriptional regulation [70]. An important feature of the Gattinara [73] genome-wide library is its small size ( 40,000 gRNAs), which allows modulation of nearly 20,000 sequences with two highly effective gRNAs per gene [73]. The recently described BARBEKO library is intended for CRISPR-ko screening using the AncBE4max cytidine base editor that introduces stop codons, disrupts start codons, and introduces splice sites into target genes [74].

Pathway-specific libraries contain fewer gRNAs owing to the limited spectrum of targeted genes, so screening specific pathways is less expensive than using the genomewide format. Genes that can be targeted with existing libraries for virological research include interferon-stimulated genes (ISGs) [75], cell surface proteins and receptors [76], and ubiquitination/deubiquitination complex genes [77]. The most common human genomewide or pathway-specific libraries are available for purchase through AddGene (Table 1).

Table 1. Currently available pre-made CRISPR libraries.

\begin{tabular}{|c|c|c|c|c|c|}
\hline $\begin{array}{l}\text { Type of } \\
\text { Screen }\end{array}$ & Library Name & $\begin{array}{c}\text { AddGene } \\
\text { Catalog Number }\end{array}$ & $\begin{array}{c}\text { Genes } \\
\text { Targeted }\end{array}$ & $\begin{array}{l}\text { gRNAs } \\
\text { Per Gene }\end{array}$ & Total gRNAs \\
\hline \multicolumn{6}{|c|}{ Genome-Wide Libraries } \\
\hline Ko & GeCKO v2 & $\begin{array}{c}1000000048 \text { and } \\
1000000049\end{array}$ & 19,052 & 6 & 123,411 \\
\hline
\end{tabular}


Table 1. Cont.

\begin{tabular}{|c|c|c|c|c|c|}
\hline $\begin{array}{l}\text { Type of } \\
\text { Screen }\end{array}$ & Library Name & $\begin{array}{c}\text { AddGene } \\
\text { Catalog Number }\end{array}$ & $\begin{array}{l}\text { Genes } \\
\text { Targeted }\end{array}$ & $\begin{array}{l}\text { gRNAs } \\
\text { Per Gene }\end{array}$ & Total gRNAs \\
\hline \multicolumn{6}{|c|}{ Genome-Wide Libraries } \\
\hline Ko & Toronto v3 & $\begin{array}{l}90294 \text { and } \\
125517\end{array}$ & 18,053 & 4 & 70,948 \\
\hline Ko & Brunello & $\begin{array}{l}73179 \text { and } \\
73178\end{array}$ & 19,114 & 4 & 76,441 \\
\hline Ko & Gattinara & 136986 & 19,993 & 2 & 40,964 \\
\hline Ko & $\begin{array}{c}\text { Mini-Human } \\
\text { AsCas12a-Based Library }\end{array}$ & 130630 & 16,997 & $3-4$ & $\begin{array}{c}\text { 17,032 arrays } \\
(3-4 \text { gRNAs per array) }\end{array}$ \\
\hline Ko & $\begin{array}{c}\text { BARBEKO (for screening with a } \\
\text { base editor) }\end{array}$ & 174163 & 17,501 & 3 & 53,502 \\
\hline CRISPRi & Dolcetto & 1000000114 & $\begin{array}{l}18,901 \text { (Set A); } \\
18,899 \text { (Set B) }\end{array}$ & $3-6$ & $\begin{array}{l}57,050 \text { (Set A); } \\
57,011 \text { (Set B) }\end{array}$ \\
\hline CRISPRi & CRISPRi-v2 & $\begin{array}{c}83969 \\
1000000090\end{array}$ & 18,905 & $5-10$ & $\begin{array}{l}104,535 \\
209,070\end{array}$ \\
\hline CRISPRa & Calabrese & 1000000111 & $\begin{array}{l}18,885 \text { (Set A); } \\
18,843 \text { (Set B) }\end{array}$ & $3-6$ & $\begin{array}{l}56,762 \text { (Set A); } \\
56,476 \text { (Set B) }\end{array}$ \\
\hline CRISPRa & CRISPRa-v2 & $\begin{array}{c}83978 \\
1000000091\end{array}$ & 18,915 & 5 or 10 & $\begin{array}{c}104,540 \text { or } \\
209,080\end{array}$ \\
\hline CRISPRa & SAM Library (3-plasmid system) & $\begin{array}{c}1000000057 \text { and } \\
1000000074\end{array}$ & 23,430 & 3 & 70,290 \\
\hline \multicolumn{6}{|c|}{ Pathway-Specific Libraries } \\
\hline Ko & $\begin{array}{l}\text { Human Interferon-Stimulated } \\
\text { Gene CRISPR Knockout Library }\end{array}$ & 125753 & 1902 & 8 & 15,416 \\
\hline Ko & $\begin{array}{l}\text { Bison sgRNA Library } \\
\text { (ubiquitination and } \\
\text { deubiquitination genes) }\end{array}$ & 169942 & 713 & 4 & 2852 \\
\hline Ko & $\begin{array}{c}\text { Li Human UBDUB CRISPR } \\
\text { Knockout Library (ubiquitination } \\
\text { and deubiquitination genes) }\end{array}$ & 171531 & 1500 & $\sim 6$ & 9274 \\
\hline CRISPRa & $\begin{array}{l}\text { Wright Human Membrane } \\
\text { Protein Activation Library } \\
\quad \text { (surface proteins) }\end{array}$ & 113345 & 6213 & $7-14$ & 58,570 \\
\hline
\end{tabular}

\subsection{Construction of Cas9- and gRNA-Encoding Vectors}

Once gRNAs are designed in silico, gRNA-encoding oligonucleotides are synthesized in microarray format and cloned into vector backbones. The cloned gRNA library is amplified in bacteria and packaged into lentiviral particles. Purified viral particles are titrated to determine the required multiplicity of infection (MOI) [78]. Since these vectors contain an antibiotic resistance gene, titration can be performed by comparing cell numbers before and after antibiotic selection [78]. Viral titers can also be determined via ELISA against the p24 capsid protein, real-time PCR detecting vector insert, fluorescent titration with flow cytometry, and other methods.

Cas9 protein can be expressed by the same vector that encodes the gRNA, or a cell line stably expressing Cas/dCas protein can be established first. Using the same vector for Cas and gRNA is simpler, but the additional Cas-expressing frame greatly increases vector size and diminishes the titer of produced lentivirus. Expressing Cas and gRNA separately reduces the probability of recombination during plasmid amplification, and a virus produced from such a vector can be manufactured with higher titers. If 
screening assumes the use of a single cell line, generating Cas/dCas-expressing clones is recommended [79].

\subsection{Lentiviral Transduction}

Once lentiviral constructs are made and titrated, target cells are transduced with these lentiviruses at MOI $\sim 0.3-0.4$ to obtain cells expressing 0 to 1 gRNA each. Transduced cells are selected by FACS or by treating with antibiotics and cultured for 7-14 days to ensure modulation of the target genes and accumulation of cell mass for subsequent analysis. The approximate number of cells at the end of this stage is calculated according to library size and should exceed 200 cells per gRNA [78].

\subsection{Selection}

Next, cells are selected based on specific markers or phenotypes via negative or positive selection (Figure 2). In negative selection, cells with the desired phenotype are depleted from the cell population. For example, cells can be treated with an anti-tumor drug, so gRNAs that inhibit a drug resistance gene induce cell death. Cells are harvested at different time points after transduction to determine which gRNAs are depleted from the cell population. During negative selection, each gRNA can be depleted from the cell population only to the extent that it was presented in the initial library. If a library consists of 100,000 gRNAs, each gRNA can only be depleted by $0-1$ per 100,000 cells, so the reduction in the overall cell pool is negligible. This limitation can be diminished by using fewer gRNAs in a library [43]. Another limitation of negative selection is cell depletion that occurs over time independent of gene modification.

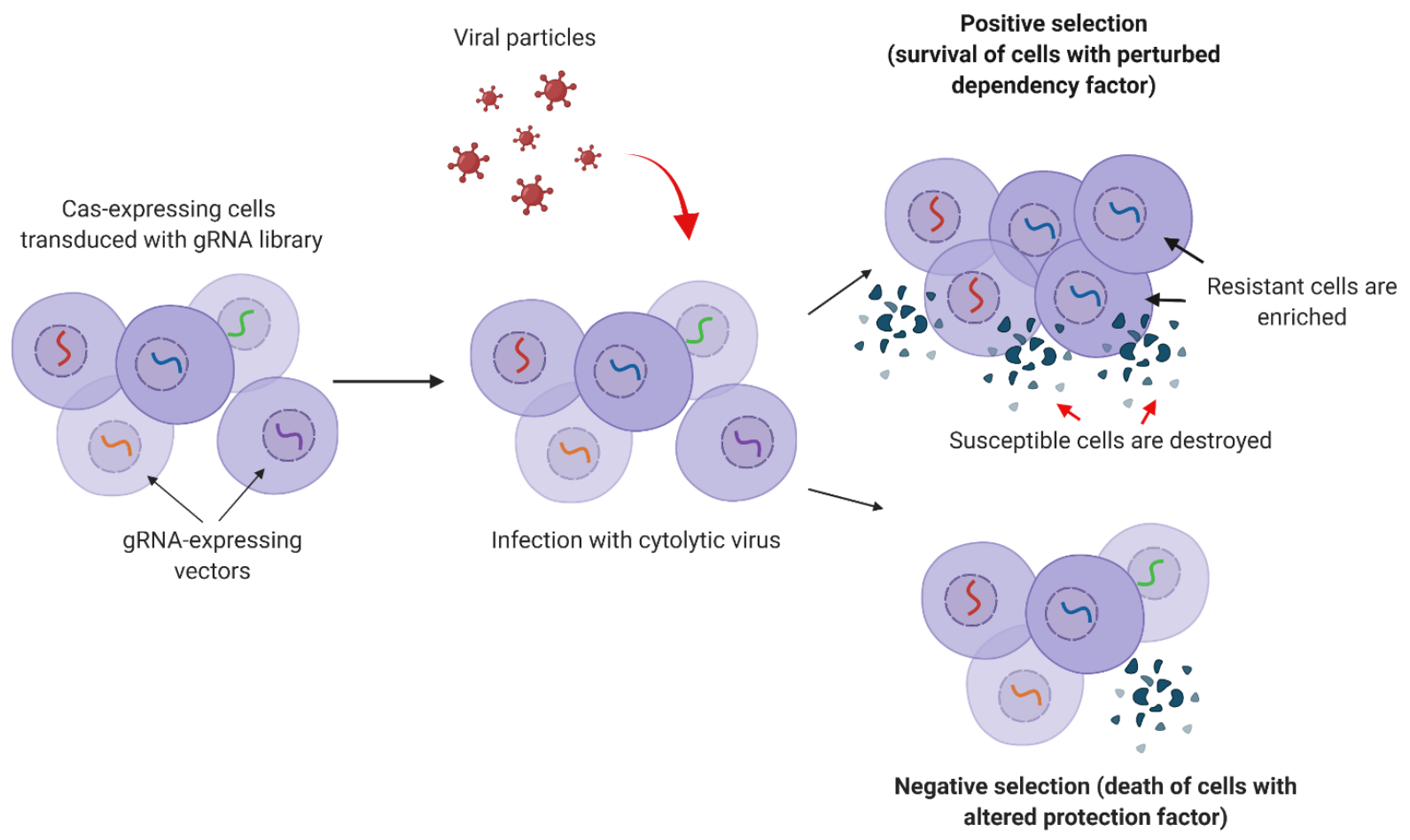

Figure 2. Positive and negative selection of cells for CRISPR screening. Cas-producing cells are transduced with the lentiviral gRNA library. Next, cells are infected with a cytolytic virus and then undergo positive selection (resistant cells are enriched while susceptible cells die) or negative selection (cells with altered antiviral genes die).

In positive selection, cells with the desired phenotype are enriched in a cell population while other cells are depleted. For example, inhibiting a gene responsible for susceptibility to a virus will allow cells to survive infection in culture. In positive selection, cells with 
a single modification can in principle be enriched to $100 \%$ of the final population, so the effect of a specific gRNA is much more evident than in negative selection.

\subsection{Sequencing}

After selection, genomic DNA of selected cells and control cells is extracted; gRNA-encoding integrations are amplified and ligated with NGS adapters. Amplicons from selected cells and control cells are sequenced with sufficient depth to define the relative abundance of each gRNA before and after selection [62].

\subsection{Data Analysis}

The final step, data analysis, can be performed with developed algorithms (MAGeCK RRA [80], MAGeCK-MLE [81], BAGEL [82], CERES [83], CRISPhieRmix [84], JACKS [85], etc.). According to a study by Bodapati et al. [39] comparing different algorithms, MAGeCK RRA performs best in most applications. When gRNA efficiency varies greatly for a single gene (often observed in CRISPRi/CRISPRa screens), CRISPhieRmix should be used, as it considers such variability. For screens that use several cell lines, common hit genes and cell-specific hit genes can be determined with MAGeCK-MLE, JACKS, and CERES [39]. The commonly used free MAGeCK algorithm has a video tutorial that allows even inexperienced users to utilize it and provides demo data sets for performing test analysis [86]. Significant fold-changes for several gRNAs targeting the same gene have higher statistical power than a single gRNA hit per gene.

The results of the screen should be further validated to exclude false-positive hits and screening bias. For validation, gRNAs for screening hit genes are cloned into individual vectors and used to reproduce the data in separate experiments. The change in target gene expression should be approved by investigating target protein levels.

A comprehensive, step-by-step protocol for different types of CRISPR screening, including detailed troubleshooting, was provided by Joung et al. [87].

\section{CRISPR Screens for Studying Viral Infections}

Viruses affect billions of people worldwide, but specific treatments are not available for most of these infections. Viruses can cause local outbreaks, epidemics, and seasonal brief infections, and many viral agents also cause chronic infections, in which the virus can persist in the body for years, damaging specific tissues, organs, or organ systems. Studying emerging, re-emerging, and persistent viruses and their interactions with host cells is crucial for understanding their biology and host response, identifying novel therapeutic targets, and determining pathways of innate immunity. CRISPR screens provide a great advantage for high-throughput analysis of viral agents and host factors for these purposes. Table 2 summarizes the results of CRISPR screen analyses for different viral infections.

Table 2. CRISPR screens for studying viral infections.

\begin{tabular}{ccccc}
\hline Virus & $\begin{array}{c}\text { Screen } \\
\text { Type }\end{array}$ & gRNA Library & Cells & Top Screening Hits \\
\hline CRISPR-ko & $\begin{array}{c}\text { Custom library of } \\
\text { 187,536 gRNAs } \\
\text { targeting 18,543 genes }\end{array}$ & GXR cell line & $\begin{array}{c}\text { TPST2, SLC35B2, ALCAM, } \\
\text { CCR5, CD4 }\end{array}$ \\
\cline { 2 - 5 } & [34] & Jurkat & $\begin{array}{c}\text { TMEM178A, FTSJ3, INTS2, } \\
\text { INTS5, INTS8, NICN1 }\end{array}$ [88] \\
\hline CRISPRi & CRISPRi-v2 & GeCKO & C11 cell line & PEPB1, BRD2, BRD4 \\
\hline CRISPR-ko & GeCKO & Jurkat & ZNF304 \\
\hline CRISPR-ko & GeCKO v2 & $\begin{array}{c}\text { Jurkat (J-Lat 10.6 } \\
\text { cell line) }\end{array}$ & $\begin{array}{c}\text { 52 genes including IWS1, } \\
\text { POLE3, POLR1B, } \\
\text { PSMD1, TGM2 }\end{array}$ \\
\hline
\end{tabular}


Table 2. Cont.

\begin{tabular}{|c|c|c|c|c|c|}
\hline Virus & $\begin{array}{l}\text { Screen } \\
\text { Type }\end{array}$ & gRNA Library & Cells & Top Screening Hits & Ref. \\
\hline & CRISPR-ko & GeCKO v2 & $\begin{array}{l}\text { Jurkat (HIV-1 latent } \\
\text { infection cell line [C11]) }\end{array}$ & $\begin{array}{c}\text { TCS1, DEPDC5, SUV39H1, } \\
\text { SPATA6L, NFKB2, and } \\
\text { other genes }\end{array}$ & [92] \\
\hline \multirow{4}{*}{$\begin{array}{c}\text { Coronaviruses } \\
\text { (SARS-CoV-2, MERS) }\end{array}$} & CRISPR-ko & Brunello & Huh-7.5 & $\begin{array}{c}146\left(37^{\circ} \mathrm{C}\right) \text { and } 171\left(33^{\circ} \mathrm{C}\right) \\
\text { genes, including } \\
\text { TMEM41B for all of } \\
\text { investigated viruses }\end{array}$ & [93] \\
\hline & CRISPR-ko & $\begin{array}{l}\text { Custom library of } \\
83,963 \text { gRNAs }\end{array}$ & Vero-E6 & $\begin{array}{l}\text { Genes of SWI/SNF } \\
\text { complex, ACE2, DPP4, } \\
\text { CTSL, PCBD1, KMT2D, } \\
\text { SMAD3, HMGB1, } \\
\text { and others }\end{array}$ & [94] \\
\hline & CRISPR-ko & GeCKO v2 & A549ACE2 & $\begin{array}{l}\text { RAB7A, CCDC22, VPS35, } \\
\text { ACE2, CTSL, and others }\end{array}$ & [95] \\
\hline & CRISPR-ko & GeCKO v2 & Huh7.5.1 & $\begin{array}{l}\text { TMEM106B and } \\
\text { other genes }\end{array}$ & [96] \\
\hline \multirow{2}{*}{$\begin{array}{l}\text { Dengue virus } \\
\quad(\mathrm{DENV})\end{array}$} & CRISPR-ko & GeCKO v2 & Haploid HAP1 cells & $\begin{array}{l}17 \text { genes including DPM1 } \\
\text { and DPM3 }\end{array}$ & [97] \\
\hline & CRISPR-ko & GeCKOv2 & Huh7.5.1 & $\begin{array}{l}\text { STT3A, STT3B, DC2, } \\
\text { MAGT, RPN2, OST4 }\end{array}$ & {$[98]$} \\
\hline $\begin{array}{l}\text { Zika virus (ZIKV), } \\
\text { yellow fever virus }\end{array}$ & CRISPR-ko & GeCKO & HAP1 & $\begin{array}{l}\text { TMEM41B and VMP1 } \\
\text { (overlap between the } \\
\text { two viruses) }\end{array}$ & [99] \\
\hline \multirow{3}{*}{ ZIKV } & CRISPR-ko & Brunello & TS576 & $\begin{array}{c}\text { CENPH, ITGB5, MYLPH, } \\
\text { HOMER1, BAALC, } \\
\text { GABBR2, EPHA10, } \\
\text { PTNP2, GCNT7, TRAM1, } \\
\text { TMEM41B }\end{array}$ & [100] \\
\hline & CRISPRa & LentiSAMv2 & Huh7 & $\begin{array}{l}\text { IFI6, IFNL2, } \\
\text { ISG20, HELZ2 }\end{array}$ & [101] \\
\hline & CRISPR-ko & $\begin{array}{l}\text { LentiCRISPRv1; } \\
\text { custom library }\end{array}$ & $\begin{array}{l}\text { Human neural } \\
\text { progenitors cells }\end{array}$ & $\begin{array}{l}\text { TM9SF2, ATP6V1C1, } \\
\text { ATP6V1F, SSR2, SSR3, } \\
\text { EMC2, EMC6, C3orf58, } \\
\text { ISG15, SOCS3, STAT3 }\end{array}$ & [102] \\
\hline $\begin{array}{l}\text { Hepatitis A } \\
\text { virus (HAV) }\end{array}$ & CRISPR-ko & Brunello & HeLa & $\begin{array}{l}39 \text { genes including UGCG, } \\
\text { GALE, and SLC35A2 }\end{array}$ & [103] \\
\hline $\begin{array}{c}\text { Hepatis B } \\
\text { virus (HBV) }\end{array}$ & CRISPR-ko & $\begin{array}{l}\text { Custom library of } \\
19,050 \text { genes, with } \\
5 \text { gRNAs/gene }\end{array}$ & HepG2 & $\begin{array}{l}22 \text { pro-HBsAg genes, } \\
\text { including ZCCHC14, } \\
\text { NXT1, and ENY2; } \\
38 \text { anti-HBsAg genes, } \\
\text { including DCAF7, UBE2J1, } \\
\text { RNF139, and UBE2J2 }\end{array}$ & [104] \\
\hline \multirow{3}{*}{ Epstein-Barr virus } & CRISPR-ko & AVANA & P3HR-1 & $\begin{array}{l}\text { MYC, EP300, STAGA, } \\
\text { FACT, cohesin subunits }\end{array}$ & [105] \\
\hline & CRISPR-ko & Brunello & $\begin{array}{l}\text { Lymphoblastoid cell } \\
\text { lines (LCL) }\end{array}$ & $\begin{array}{c}\text { TAF family } \\
\text { proteins, MEF2C }\end{array}$ & [106] \\
\hline & CRISPR-ko & Avana & P3HR-1, GM12878 & $\begin{array}{l}57 \text { genes for P3HR1 and } \\
87 \text { genes for GM12878 }\end{array}$ & [107] \\
\hline
\end{tabular}


Table 2. Cont.

\begin{tabular}{|c|c|c|c|c|c|}
\hline Virus & $\begin{array}{l}\text { Screen } \\
\text { Type }\end{array}$ & gRNA Library & Cells & Top Screening Hits & Ref. \\
\hline \multirow{2}{*}{$\begin{array}{l}\text { Human } \\
\text { cytomegalovirus } \\
(\mathrm{HCMV})\end{array}$} & CRISPR-ko & GeCKO v2 & $\begin{array}{c}\text { ARPE-19; } \\
\text { HEL fibroblasts }\end{array}$ & OR14I1, PDGFRA & [108] \\
\hline & CRISPR-ko & GeCKO v2 & $\begin{array}{l}\text { Human foreskin } \\
\text { fibroblasts (HFF) }\end{array}$ & PDGFRA & [109] \\
\hline \multirow{2}{*}{$\begin{array}{l}\text { Influenza A } \\
\text { virus (IAV) }\end{array}$} & CRISPR-ko & AVANA-4 & A549 & $\begin{array}{l}\text { WDR7, CCDC115, } \\
\text { TMEM199, CMTR1 }\end{array}$ & [110] \\
\hline & CRISPR-ko & $\mathrm{GeCKO}$ & A549 & SLC35A1 and other genes & [111] \\
\hline \multirow{2}{*}{$\begin{array}{l}\text { Adeno- } \\
\text { associated virus }\end{array}$} & CRISPR-ko & GeCKO & Huh7 & $\begin{array}{l}\text { GPR108, NEU1, } \\
\text { GCNT4, CTSA }\end{array}$ & [112] \\
\hline & CRISPR-ko & GeCKO v2 & Huh7 & Crb3, CLDN15 & [113] \\
\hline Ebola virus (EBOV) & CRISPR-ko & GeCKO v2 & Huh7.5.1 & $\begin{array}{c}\text { GNPTAB, NPC1, SPNS1, } \\
\text { SLC30A1, HOPS } \\
\text { complex, UVRAG }\end{array}$ & [114] \\
\hline $\begin{array}{c}\text { Enteroviruses } \\
\text { (RV-C15 and } \\
\text { non-polio EV-D68) }\end{array}$ & CRISPR-ko & GeCKO v2 & H1-HeLa cells & SETD3, CSDE1, PLA2G16 & [115] \\
\hline $\begin{array}{l}\text { Severe fever with } \\
\text { thrombocytopenia } \\
\text { syndrome virus }\end{array}$ & CRISPR-ko & GeCKO v2 & $\mathrm{HeLa}$ & SNX11 & [116] \\
\hline $\begin{array}{l}\text { Norovirus } \\
\text { restriction factors }\end{array}$ & CRISPRa & Calabrese & Hela & $\begin{array}{l}\text { TRIM7, PITX1, HOXC11, } \\
\text { DDX60, MX1, PLSCR1 }\end{array}$ & [117] \\
\hline \multirow[b]{2}{*}{ Flaviviruses } & CRISPR-ko & Brunello & Huh7.5 & IFI6, STAT2, IRF9 & [118] \\
\hline & CRISPR-ko & GeCKO v2 & $293 \mathrm{~T}$ & $\begin{array}{l}\text { STT3A, SEC63, } \\
\text { SPCS1, SPCS3 }\end{array}$ & [119] \\
\hline West Nile virus & CRISPR-ko & $\begin{array}{c}\text { Custom library of } \\
\text { 77,406 gRNAs } \\
\text { covering 20,121 genes }\end{array}$ & $293 \mathrm{FT}$ & $\begin{array}{l}\text { EMC2, EMC3, SEL1L, } \\
\text { DERL2, UBE2G2, } \\
\text { UBE2J1, HRD1 }\end{array}$ & [120] \\
\hline $\begin{array}{c}\text { Arthritogenic } \\
\text { alphaviruses } \\
\text { (chikungunya, Ross } \\
\text { River, Mayaro, } \\
\text { O'nyong nyong) }\end{array}$ & CRISPR-ko & GeCKO v2 & $3 \mathrm{~T} 3$ & MXRA8 & [121] \\
\hline Rotavirus & CRISPR-ko & GeCKO & H1-Hela & $\begin{array}{c}\text { SLC35A1, GNE, CMAS, } \\
\text { UGCG, FA2H, } \\
\text { LATS2, STAG2 }\end{array}$ & [122] \\
\hline
\end{tabular}

\subsection{CRISPR Screens for Studying Virus-Host Interactions}

5.1.1. Virus Entry and Transmission

Genome-wide screens are often used for basic research in virology and for identifying factors responsible for virus entry into cells and transmission of infection. Hepatitis A virus (HAV) host dependency factors were first investigated using CRISPR screening by Das et al. in 2020 [103]. The study found that components of the ganglioside synthetic pathway are important for HAV entry into cells, and that viral capsids are not uncoated inside ganglioside-deficient cells.

Wei et al. developed another custom gRNA library to analyze severe acute respiratory syndrome coronavirus 2 (SARS-CoV-2) using a CRISPR screen approach. The most prominent hits included high-mobility group protein B1 (HMGB1), which upregulates expression of SARS-CoV-2 entry receptor ACE2. Disrupting the HMGB1 gene in susceptible cells 
reduced the abundance of active chromatin modifications at the regulatory elements of the ACE2 promoter [94].

In 2017, Park et al. [34] performed a genome-wide CRISPR-ko screen to reveal the factors required for human immunodeficiency virus (HIV) entry and replication. CRISPR screens both confirmed the role of previously described pro-HIV factors like CD4 and CCR5, proving the validity of the screen, and identified three additional factors involved in HIV replication: tyrosylprotein sulfotransferase 2 (TPST2), solute carrier family 35 member B2 (SLC35B2), and activated leukocyte cell adhesion molecule (ALCAM). TPST2 was found to contribute to CCR sulfation, required for HIV-CCR5 interaction. SCL35B2 was shown to be involved in the transportation of $3^{\prime}$-phosphoadenosine- $5^{\prime}$-phosphosulfate, a donor of sulfate groups. Depleting SCL35B2 resulted in deficient CCR5 sulfation and impaired HIV entry. Additionally, ALCAM deficiency diminished cell-to-cell transmission of HIV.

Several CRISPR screen studies were performed to investigate human cytomegalovirus (HCMV) host dependency factors. Wu et al. revealed PDGFR $\alpha$ as a top screening hit required for trimer-mediated HCMV entry, as well as for cell-to-cell spread of trimer-only HCMV. Pentamer-containing viruses still infected the PDGFRA-deficient cell, albeit with lower efficiency [109]. A different study demonstrated that the sensitivity of epithelial cells to infection with pentamer HCMV is mediated by OR14I1 protein. PDGFRA and OR14I1 factors were shown to serve as non-redundant co-receptors for HCMV pentameric complex [108].

\subsubsection{Viral Replication}

Hoffman et al. used custom library CRISPR screens to study SARS-CoV-2 interactome with infected cells [123]. Along with SARS-CoV-2, the authors utilized the CRISPR screen to search for pan-coronavirus factors required for replication in models of $\mathrm{HCoV}$ NL63, HCoV-229E, and HCoV-OC43 infection. Sterol regulatory element-binding protein cleavage-activating protein (SCAP) was identified as the host factor important for replication of all four coronaviruses. In healthy cells, SCAP regulates lipid and cholesterol homeostasis by sequestering sterol regulatory element-binding proteins in the endoplasmic reticulum. SCAP may promote coronavirus infection by hijacking SREBPs-dependent transport and/or by potentiating viral interactions with cell membranes when cholesterol content is increased [124].

\subsubsection{Viral Protein Stability}

Lin et al. studied virus-host interaction factors of dengue virus (DENV) infection using a CRISPR-ko screen, showing the importance of host factor MAGT1 [98]. Two subunits of DPMS complex (DMP1 and DMP3) were also demonstrated to play a role in DENV infection by regulating DENV replication and enhancing viral structural glycoprotein stability [97].

\subsection{CRISPR Screens for Identifying New Antiviral Targets}

The search for new therapeutic targets for treating viral diseases is an important branch of drug discovery. CRISPR screens make it possible to search for viral host factors important for viral replication and maintenance in a high-throughput manner.

\subsubsection{Latency}

In 2018, Jin et al. used CRISPR screening to identify genes maintaining HIV latency, a state in which the integrated provirus is not transcribed [92]. Latency allows HIV persistence and prevents immune-mediated clearance of infected cells. Reactivating the latent provirus along with anti-retroviral therapy is a shock-and-kill strategy that can potentially destroy latent reservoirs and eliminate the virus. Thus, identifying new targets for reactivating HIV is important for developing novel therapeutic approaches. CRISPR-ko screening revealed that TSC1 and DEPDC5 maintained suppression of AKT-mTORC1 signaling, thus promoting HIV latency. Inactivating these genes induced activity of the AKT-mTORC1 
axis and stimulated HIV replication [92]. In another study, Li et al. (2020) used genomewide CRISPRi screening to demonstrate that inhibiting FTSJ3, TMEM178A, and NICN1 genes stimulated RNA polymerase II-mediated transcription of HIV, promoting its latency. Further immunoprecipitation experiments showed that depleting TMEM178A and NICN1 increased polymerase II signaling on HIV's long terminal repeat (LTR) regulatory elements and envelope region. Thus, these two genes affect both initiation and elongation of HIV-1 transcription. Depleting FTSJ3 and INTS2 increased polymerase II signaling in the envelope region but not in LTR, suggesting a role for these proteins in elongation [88]. A CRISPR-ko screen by Yang et al. revealed phosphatidylethanolamine-binding protein 1 (PEBP1) as a gene promoting HIV latency via dephosphorylation-mediated inactivation of MAPK and NF-kB signaling pathways [89]. KRAB-containing zinc-finger protein ZNF304 was recently identified in a CRISPR screen as a silencer of the HIV promoter, and, thus, as a factor promoting HIV latency [90]. Rathore et al. used a CRISPR-ko screen to discover additional genes involved in HIV latency, including IWS1, POLE3, POLR1B, PSMD1, TGM2, UCH37, CYLD, A 20, OTULIN, USP5, and USP14. Pharmacological inhibition of some factors, such as UCH37 and USP14, reversed HIV latency and induced provirus reactivation [91]. Overall, these studies provide valuable information about potential drug targets to reactivate HIV replication and develop novel antiviral approaches for HIV patients.

\subsubsection{Entry}

Schneider et al. conducted a genome-wide CRISPR-ko screen in models of natural SARS-CoV-2 infection at temperatures observed in the upper $\left(33^{\circ} \mathrm{C}\right)$ and lower $\left(37^{\circ} \mathrm{C}\right)$ respiratory tract [93]. One of the top screening hits was ACE2, a previously established receptor for SARS-CoV-2. In primary analysis, $84\left(37^{\circ} \mathrm{C}\right)$ and $99\left(33^{\circ} \mathrm{C}\right)$ genes were shown to facilitate SARS-CoV-2 infection. Among these, transmembrane protein 41B (TMEM41B) was one of the most important host factors required for infection by SARS-CoV-2 and other seasonal coronaviruses (HCoV-OC43, HCoV-NL63, and HCoV-229E). The role of TMEM41B in the SARS-CoV-2 life cycle is not unique to coronaviruses, as TMEM41B is also important for infection by flaviviruses (for example, Zika virus (ZIKV)) [93].

In 2019, a wide-genome CRISPR screen was implemented by Flint et al. in a search for host factors required for Ebola virus (EBOV) replication. GNPTAB, which encodes $\mathrm{N}$-acetylglucosamine-1-phosphate transferase, was identified. The authors showed that EBOV infection was inhibited in the absence of GNPTAB, concluding that disrupting GNTAB function can be a strategy for treating EBOV infection [114].

\subsubsection{Protein Translation}

Hepatitis B virus (HBV) causes one of the most widespread viral infections, inducing cirrhosis and hepatocellular carcinoma. Currently, therapy can suppress viral replication and reduces the risks of severe outcomes. In 2019, Hyrina et al. performed a CRISPR screen to identify host factors required for viral replication and production of $\mathrm{HBsAg}$, an important biomarker of viral replication [104]. Top hits included zinc-finger CCHCtype containing 14 (ZCCHC14) protein, which was shown to stabilize HBV S-mRNA and promote HBsAg expression. Additionally, $\sim 60$ genes were shown to influence HBsAg levels. All identified genes are potential therapeutic targets for managing chronic $\mathrm{HBV}$ infection. Clearance of HBsAg in patients with chronic HBV infection is a major therapeutic target that may help to provide durable control over viral replication and substantially reduce the risk of liver cirrhosis and hepatocellular carcinoma [125].

CRISPR screen technology is suitable for finding new therapeutic targets to treat viral infections. The most potent target factors can be blocked by small-molecule inhibitors, monoclonal antibodies, or RNA interference drugs for antiviral therapy. Additionally, factors with pronounced antiviral effects can be upregulated using CRISPRa or other strategies for therapeutic purposes [126-128]. 


\subsection{Immunity Studies}

Richardson et al. used CRISPR screening to identify genes that regulate interferon (IFN) response to flavivirus infection. Cells were treated with a high dose of IFN- $\alpha$ before running a CRISPR screen to identify factors that make cells susceptible to infection. Members of IFN- $\alpha$ signaling pathway IFNAR1, IFNAR2, IRF9, and ISG effector gene IFI6 were revealed as factors with the highest antiviral activity. The authors showed that IFI16 prevents formation of virus-induced invaginations in the endoplasmic reticulum membrane and impairs viral replication [118].

OhAinle et al. created an ISG targeting library to study HIV infection, showing that a set of ISGs (MxB, TRIM5 $\alpha$, IFITM1, and tetherin) effectively suppressed HIV-1 infection, although, individually, these factors had modest antiviral effects [129]. These findings indicated that instead of using single genes as candidate drug targets, concerted activation of multiple genes is sometimes required to achieve effective viral suppression. In another CRISPR-ko screen targeting 1906 human ISGs with 8 gRNAs per gene, Roesch et al. (2018) identified IFITM factors as potent inhibitors of lentiviral particle delivery. IFITM1/3 showed an evident antiviral effect in a model of VSV-g pseudotyped viral-like particles encoding the HIV Vpx gene [75].

Using a CRISPR-ko screen, Li et al. (2019) showed that ZIKV replication relies on many host factors involved in heparin sulfation, endocytosis, and endoplasmic reticulum protein processing. Also, ZIKV actively suppresses the IFN pathway (ISG15 and others), and knocking out ISG15 protected human neural progenitor cells from ZIKV [102]. In 2019, Dukhovny [101] identified that other ISGs, such as IFNL2 and IFI6, can rescue cells from ZIKV infection. Another study using a CRISPR-ko screen [100] identified integrin $\alpha \mathrm{v} \beta 5$ as a potential therapeutic target for ZIKV; $\alpha \mathrm{v} \beta 5$ directly interacts with ZIKV and provides the molecular basis for ZIKV internalization.

Using a CRISPR-ko screen, Chia et al. identified genes restricting influenza A virus (IAV) after IFN type I treatment. Along with key components of IFN signaling, replication termination factor 2 (RTF2), a new factor suppressing IAV transcription and upregulation of antiviral networks was identified [130] in this screen.

To conclude, genome-wide CRISPR screens are powerful tools for studying virus-host interactions and for identifying potential therapeutic targets for treating viral infections. Differences in data sets from independent CRISPR screens for the same viral infections can be explained by differences in experimental setups, models of infection used, or types of CRISPR screening. However, most screening hits typically overlap between studies. To increase the statistical power of studies, top hit genes should be validated in different models of viral infection.

\section{Conclusions}

In this paper, we describe the main types, principles, and steps of CRISPR screens. Since their adaptation for genome-wide screening, CRISPR tools have contributed greatly to fundamental and translational studies. Many types of Cas proteins and sgRNAs have been used to develop gain-of-function CRISPRa and loss-of-function CRISPRi tools, as well as nuclease-based and base editor-mediated approaches. Additionally, CRISPR screening approaches have become powerful tools for studying viral infections, identifying host dependency factors and novel drug targets. Given the recent breakthroughs in artificial intelligence and modeling of protein 3D structures, designing new small molecules has become much more efficient. Combining these approaches will advance drug discovery in the coming years. Combinatorial CRISPR screens provide the opportunity to analyze complex biological processes and define the effective combinations of antiviral factors with initially low or mediocre antiviral activity. This will be important for optimizing existing therapeutic approaches and developing new ones.

Funding: This research was funded by RSF No 20-15-00373.

Conflicts of Interest: The authors declare no conflict of interest. 


\section{References}

1. Brezgin, S.; Kostyusheva, A.; Kostyushev, D.; Chulanov, V. Dead Cas Systems: Types, Principles, and Applications. Int. J. Mol. Sci. 2019, 20, 6041. [CrossRef] [PubMed]

2. Brezgin, S.; Kostyusheva, A.; Bayurova, E.; Volchkova, E.; Gegechkori, V.; Gordeychuk, I.; Glebe, D.; Kostyushev, D.; Chulanov, V. Immunity and Viral Infections: Modulating Antiviral Response via CRISPR-Cas Systems. Viruses 2021, 13, 1373. [CrossRef] [PubMed]

3. Parnas, O.; Jovanovic, M.; Eisenhaure, T.M.; Herbst, R.H.; Dixit, A.; Ye, C.J.; Przybylski, D.; Platt, R.J.; Tirosh, I.; Sanjana, E.N.; et al. A genome-wide CRISPR screen in primary immune cells to dissect regulatory networks. Cell 2015, 162, 675-686. [CrossRef] [PubMed]

4. Zetsche, B.; Gootenberg, J.S.; Abudayyeh, O.O.; Slaymaker, I.M.; Makarova, K.S.; Essletzbichler, P.; Volz, S.E.; Joung, J.; van der Oost, J.; Regev, A.; et al. Cpf1 Is a Single RNA-Guided Endonuclease of a Class 2 CRISPR-Cas System. Cell 2015, 163, 759-771. [CrossRef]

5. Wang, X.; Li, J.; Wang, Y.; Yang, B.; Wei, J.; Wu, J.; Wang, R.; Huang, X.; Chen, J.; Yang, L. Efficient base editing in methylated regions with a human APOBEC3A-Cas9 fusion. Nat. Biotechnol. 2018, 36, 946. [CrossRef] [PubMed]

6. Yu, Y.; Leete, T.C.; Born, D.A.; Young, L.; Barrera, L.A.; Lee, S.-J.; Rees, H.A.; Ciaramella, G.; Gaudelli, N.M. Cytosine base editors with minimized unguided DNA and RNA off-target events and high on-target activity. Nat. Commun. 2020, 11, 1-10. [CrossRef]

7. Ma, Y.; Zhang, J.; Yin, W.; Zhang, Z.; Song, Y.; Chang, X. Targeted AID-mediated mutagenesis (TAM) enables efficient genomic diversification in mammalian cells. Nat. Methods. 2016, 13, 1029. [CrossRef] [PubMed]

8. Friedman, J.R.; Fredericks, W.J.; Jensen, D.E.; Speicher, D.W.; Huang, X.-P.; Neilson, E.G.; Rauscher, F.J., 3rd. KAP-1, a novel corepressor for the highly conserved KRAB repression domain. Genes. Dev. 1996, 10, 2067-2078. [CrossRef]

9. Parsi, K.M.; Hennessy, E.; Kearns, N.; Maehr, R. Using an inducible CRISPR-dCas9-KRAB effector system to dissect transcriptional regulation in human embryonic stem cells. Methods Mol. Biol. 2017, 1507, 221-233. [CrossRef]

10. Chen, X.; Wei, M.; Liu, X.; Song, S.; Wang, L.; Yang, X.; Song, Y. Construction and validation of the CRISPR/dCas9-EZH2 system for targeted H3K27Me3 modification. Biochem. Biophys. Res. Commun. 2019, 511, 246-252. [CrossRef]

11. Yeo, N.C.; Chavez, A.; Lance-Byrne, A.; Chan, Y.; Menn, D.; Milanova, D.; Kuo, C.C.; Guo, X.; Sharma, S.; Tung, A.; et al. An enhanced CRISPR repressor for targeted mammalian gene regulation. Nat. Methods 2018, 15, 611. [CrossRef]

12. Huang, Y.-H.; Su, J.; Lei, Y.; Brunetti, L.; Gundry, M.C.; Zhang, X.; Jeong, M.; Li, W.; Goodell, M.A. DNA epigenome editing using CRISPR-Cas SunTag-directed DNMT3A. Genome Biol. 2017, 18, 176. [CrossRef] [PubMed]

13. Stepper, P.; Kungulovski, G.; Jurkowska, R.Z.; Chandra, T.; Krueger, F.; Reinhardt, R.; Reik, W.; Jeltsch, A.; Jurkowski, T.P. Efficient targeted DNA methylation with chimeric dCas9-Dnmt3a-Dnmt3L Methyltransferase. Nucleic. Acids Res. 2018, 45, 1703-1713. [CrossRef] [PubMed]

14. Chedin, F.; Lieber, M.R.; Hsieh, C.-L. The DNA methyltransferase-like protein DNMT3L stimulates de novo methylation by Dnmt3a. Proc. Natl. Acad. Sci. USA 2002, 99, 16916-16921. [CrossRef] [PubMed]

15. Guo, J.U.; Su, Y.; Zhong, C.; Ming, G.; Song, H. Hydroxylation of 5-Methylcytosine by TET1 Promotes Active DNA Demethylation in the Adult Brain. Cell 2011, 145, 423-434. [CrossRef] [PubMed]

16. Chavez, A.; Scheiman, J.; Vora, S.; Pruitt, B.W.; Tuttle, M.; Iyer, E.P.R.; Lin, S.; Kiani, S.; Guzman, C.D.; Wiegand, D.J.; et al. Highly efficient Cas9-mediated transcriptional programming. Nat. Methods 2015, 12, 326. [CrossRef]

17. Fang, L.; Hung, S.S.C.; Yek, J.; El Wazan, L.; Nguyen, T.; Khan, S.; Lim, S.Y.; Hewitt, A.W.; Wong, R.C.B. A Simple Cloning-free Method to Efficiently Induce Gene Expression Using CRISPR/Cas9. Mol. Ther. Nucleic Acids 2019, 14, 184-191. [CrossRef]

18. Zhang, Y.; Yin, C.; Zhang, T.; Li, F.; Yang, W.; Kaminski, R.; Fagan, P.R.; Putatunda, R.; Young, W.B.; Khalili, K.; et al. CRISPR/gRNA-directed synergistic activation mediator (SAM) induces specific, persistent and robust reactivation of the HIV-1 latent reservoirs. Sci. Rep. 2015, 5, 16277. [CrossRef]

19. Ji, H.; Jiang, Z.; Lu, P.; Ma, L.; Li, C.; Pan, H.; Fu, Z.; Qu, X.; Wang, P.; Deng, J.; et al. Specific reactivation of latent HIV-1 by dCas9-SunTag-VP64-mediated guide RNA targeting the HIV-1 promoter. Mol. Ther. 2016, 24, 508-521. [CrossRef]

20. Kim, Y.B.; Komor, A.C.; Levy, J.M.; Packer, M.S.; Zhao, K.T.; Liu, D.R. Increasing the genome-targeting scope and precision of base editing with engineered Cas9-cytidine deaminase fusions. Nat. Biotechnol. 2017, 35, 371. [CrossRef]

21. Rees, H.A.; Liu, D.R. Base editing: Precision chemistry on the genome and transcriptome of living cells. Nat. Rev. Genet. 2018, 19, 770-788. [CrossRef] [PubMed]

22. Thakore, P.I.; Ippolito, A.M.D.; Song, L.; Safi, A.; Shivakumar, N.K.; Kabadi, A.M.; Reddy, T.E.; Crawford, G.E.; Gersbach, C.A. Highly specific epigenome editing by CRISPR-Cas9 repressors for silencing of distal regulatory elements. Nat. Methods 2015, 12, 1143-1149. [CrossRef] [PubMed]

23. Nuñez, J.K.; Chen, J.; Pommier, G.C.; Cogan, J.Z.; Replogle, J.M.; Adriaens, C.; Ramadoss, G.N.; Shi, Q.; Hung, K.L.; Samelson, A.J.; et al. Genome-wide programmable transcriptional memory by CRISPR-based epigenome editing. Cell 2021, 184, $2503-2519$. [CrossRef] [PubMed]

24. Brocken, D.J.W.; Tark-Dame, M.; Dame, R.T. dCas9: A Versatile Tool for Epigenome Editing. Curr. Issues Mol. Biol. 2018, 26, 15-32. [CrossRef]

25. Adli, M. The CRISPR tool kit for genome editing and beyond. Nat. Commun. 2018, 9, 1911. [CrossRef] [PubMed]

26. Xu, X.; Qi, L.S. A CRISPR-dCas toolbox for genetic engineering and synthetic biology. J. Mol. Biol. 2019, 431, 34-47. [CrossRef] 
27. Tan, J.; Martin, S.E. Validation of synthetic CRISPR reagents as a tool for arrayed functional genomic screening. PLoS ONE 2016, 11, e0168968. [CrossRef]

28. Billon, P.; Bryant, E.E.; Joseph, S.A.; Nambiar, T.S.; Hayward, S.B.; Rothstein, R.; Ciccia, A. CRISPR-Mediated Base Editing Enables Efficient Disruption of Eukaryotic Genes through Induction of STOP Codons. Mol. Cell 2017, 67, 1068. [CrossRef] [PubMed]

29. Kuscu, C.; Parlak, M.; Tufan, T.; Yang, J.; Szlachta, K.; Wei, X.; Mammadov, R.; Adli, M. CRISPR-STOP: Gene silencing through base-editing-induced nonsense mutations. Nat. Methods 2017, 14, 710. [CrossRef]

30. López-Ferreras, L.; Martínez-García, N.; Maeso-Alonso, L.; Martín-López, M.; Díez-Matilla, Á.; Villoch-Fernandez, J.; Alonso-Olivares, H.; Marques, M.M.; Marin, M.C. Deciphering the nature of Trp73 isoforms in mouse embryonic stem cell models: Generation of isoform-specific deficient cell lines using the CRISPR/Cas9 gene editing system. Cancers 2021, 13, 3182. [CrossRef]

31. Cuella-Martin, R.; Hayward, S.B.; Fan, X.; Chen, X.; Huang, J.-W.; Taglialatela, A.; Leuzzi, G.; Zhao, J.; Rabadan, R.; Lu, C.; et al. Functional interrogation of DNA damage response variants with base editing screens. Cell 2021, 184, 1081-1097. [CrossRef]

32. Lin, J.; Wu, S.; Shen, Q.; Liu, J.; Huang, S.; Peng, G.; Qiao, Y. Base editing-mediated perturbation of endogenous PKM1/2 splicing facilitates isoform-specific functional analysis in vitro and in vivo. Cell Prolif. 2021, 54, e13096. [CrossRef]

33. Anzalone, A.V.; Koblan, L.W.; Liu, D.R. Genome editing with CRISPR-Cas nucleases, base editors, transposases and prime editors. Nat. Biotechnol. 2020, 38, 824-844. [CrossRef] [PubMed]

34. Park, R.J.; Wang, T.; Koundakjian, D.; Hultquist, J.F.; Lamothe-Molina, P.; Monel, B.; Schumann, K.; Yu, H.; Krupzcak, K.M.; Garcia-Beltran, W.; et al. A genome-wide CRISPR screen identifies a restricted set of HIV host dependency factors. Nat. Genet. 2017, 49, 193-203. [CrossRef] [PubMed]

35. Krey, K.; Babnis, A.W.; Pichlmair, A. System-Based Approaches to Delineate the Antiviral Innate Immune Landscape. Viruses 2020, 12, 1196. [CrossRef] [PubMed]

36. Tanenbaum, M.E.; Gilbert, L.A.; Qi, L.S.; Weissman, J.S.; Vale, R.D. A Protein-Tagging System for Signal Amplification in Gene Expression and Fluorescence Imaging. Cell 2014, 159, 635-646. [CrossRef]

37. Gilbert, L.A.; Horlbeck, M.A.; Adamson, B.; Villalta, J.E.; Chen, Y.; Whitehead, E.H.; Guimaraes, C.; Panning, B.; Ploegh, H.L.; Bassik, M.C.; et al. Genome-scale CRISPR-mediated control of gene repression and activation. Cell 2014, 159, 647-661. [CrossRef]

38. Fortin, J.-P.; Tan, J.; Gascoigne, K.E.; Haverty, P.M.; Forrest, W.F.; Costa, M.R.; Martin, S.E. Multiple-gene targeting and mismatch tolerance can confound analysis of genome-wide pooled CRISPR screens. Genome. Biol. 2019, 20, 1-25. [CrossRef]

39. Bodapati, S.; Daley, T.P.; Lin, X.; Zou, J.; Qi, L.S. A benchmark of algorithms for the analysis of pooled CRISPR screens. Genome. Biol. 2020, 21, 1-13. [CrossRef]

40. DeWeirdt, P.C.; Sanson, K.R.; Sangree, A.K.; Hegde, M.; Hanna, R.E.; Feeley, M.N.; Griffith, A.L.; Teng, T.; Borys, S.M.; Strand, C.; et al. Optimization of AsCas12a for combinatorial genetic screens in human cells. Nat. Biotechnol. 2021, 39, 94-104. [CrossRef]

41. Campa, C.C.; Weisbach, N.R.; Santinha, A.J.; Incarnato, D.; Platt, R.J. Multiplexed genome engineering by Cas12a and CRISPR arrays encoded on single transcripts. Nat. Methods. 2019, 16, 887-893. [CrossRef]

42. Zhou, P.; Chan, B.K.C.; Wan, Y.K.; Wong, K.H.; Chan, H.Y.E.; Wong, A.S.L. Article A Three-Way Combinatorial CRISPR Screen for Analyzing Interactions among Druggable Targets 11 A Three-Way Combinatorial CRISPR Screen for Analyzing Interactions among Druggable Targets. CellReports 2020, 32, 108020. [CrossRef]

43. Hartenian, E.; Doench, J.G. Genetic screens and functional genomics using CRISPR/Cas9 technology. FEBS J 2015, $282,1383-1393$. [CrossRef] [PubMed]

44. Xu, H.; Xiao, T.; Chen, C.-H.; Li, W.; Meyer, C.A.; Wu, Q.; Cong, L.; Zhang, F.; Liu, J.S. Sequence determinants of improved CRISPR sgRNA design. Genome. Res. 2015, 25, 1147-1157. [CrossRef] [PubMed]

45. Doench, J.G.; Hartenian, E.; Graham, D.B.; Tothova, Z.; Hegde, M.; Smith, I.; Sullender, M.; Ebert, B.L.; Xavier, R.J.; Root, D.E. Rational design of highly active sgRNAs for CRISPR-Cas9-mediated gene inactivation. Nat. Biotechnol. 2014, 32, 1262-1267. [CrossRef]

46. Doench, J.G.; Fusi, N.; Sullender, M.; Hegde, M.; Vaimberg, E.W.; Donovan, K.F.; Smith, I.; Tothova, Z.; Wilen, C.; Orchard, R.; et al. Optimized sgRNA design to maximize activity and minimize off-target effects of CRISPR-Cas9. Nat. Biotechnol. 2016, 34, 184. [CrossRef]

47. Moreno-Mateos, M.A.; Vejnar, C.E.; Beaudoin, J.; Fernandez, J.P.; Mis, E.K.; Khokha, M.K.; Giraldex, A.J. CRISPRscan: Designing highly efficient sgRNAs for CRISPR-Cas9 targeting in vivo. Nat. Methods 2015, 12, 982-988. [CrossRef]

48. Labuhn, M.; Adams, F.F.; Ng, M.; Knoess, S.; Schambach, A.; Charpentier, E.M.; Schwarzer, A.; Mateo, J.L.; Klusmann, J.H.; Heckl, D. Refined sgRNA efficacy prediction improves large-and small-scale CRISPR-Cas9 applications. Nucleic Acids Res. 2018, 46, 1375-1385. [CrossRef]

49. Labun, K.; Montague, T.G.; Krause, M.; Torres Cleuren, Y.N.; Tjeldnes, H.; Valen, E. CHOPCHOP v3: Expanding the CRISPR web toolbox beyond genome editing. Nucleic Acids Res. 2019, 47, W171-W174. [CrossRef]

50. Heigwer, F.; Kerr, G.; Boutros, M. E-CRISP: Fast CRISPR target site identification. Nat Methods 2014, 11, 122-123. [CrossRef]

51. Haeussler, M.; Schönig, K.; Eckert, H.; Eschstruth, A.; Mianné, J.; Renaud, J.-B.; Schneider-Maunoury, S.; Shkumatava, A.; Teboul, L.; Kent, J.; et al. Evaluation of off-target and on-target scoring algorithms and integration into the guide RNA selection tool CRISPOR. Genome. Biol. 2016, 17, 1-12. [CrossRef] 
52. Stemmer, M.; Thumberger, T.; del Sol Keyer, M.; Wittbrodt, J.; Mateo, J.L. CCTop: An intuitive, flexible and reliable CRISPR/Cas9 target prediction tool. PLOS ONE 2015, 10, e0124633.

53. Oliveros, J.C.; Franch, M.; Tabas-Madrid, D.; San-León, D.; Montoliu, L.; Cubas, P.; Pazos, F. Breaking-Cas-interactive design of guide RNAs for CRISPR-Cas experiments for ENSEMBL genomes. Nucleic Acids Res. 2016, 44, W267-W271. [CrossRef] [PubMed]

54. Perez, A.R.; Pritykin, Y.; Vidigal, J.A.; Chhangawala, S.; Zamparo, L.; Leslie, C.S.; Ventura, A. GuideScan software for improved single and paired CRISPR guide RNA design. Nat. Biotechnol. 2017, 35, 347-349. [CrossRef] [PubMed]

55. Li, T.; Wang, S.; Luo, F.; Wu, F.-X.; Wang, J. MultiGuideScan: A multi-processing tool for designing CRISPR guide RNA libraries. Bioinformatics 2020, 36, 920-921. [CrossRef] [PubMed]

56. Ma, J.; Köster, J.; Qin, Q.; Hu, S.; Li, W.; Chen, C.; Cao, Q.; Wang, J.; Mei, S.; Liu, Q.; et al. CRISPR-DO for genome-wide CRISPR design and optimization. Bioinformatics 2016, 32, 3336-3338. [CrossRef] [PubMed]

57. Wong, N.; Liu, W.; Wang, X. WU-CRISPR: Characteristics of functional guide RNAs for the CRISPR/Cas9 system. Genome Biol. 2015, 16, 1-8. [CrossRef]

58. Chen, C.-L.; Rodiger, J.; Chung, V.; Viswanatha, R.; Mohr, S.E.; Hu, Y.; Perrimon, N. SNP-CRISPR: A web tool for SNP-specific genome editing. G3 Genes Genomes Genet. 2020, 10, 489-494. [CrossRef]

59. Cui, Y.; Xu, J.; Cheng, M.; Liao, X.; Peng, S. Review of CRISPR/Cas9 sgRNA design tools. Interdiscip. Sci. Comput. Life Sci. 2018, 10, 455-465. [CrossRef]

60. Liu, G.; Zhang, Y.; Zhang, T. Computational approaches for effective CRISPR guide RNA design and evaluation. Comput. Struct Biotechnol. J. 2020, 18, 35-44. [CrossRef]

61. Horlbeck, M.A.; Gilbert, L.A.; Villalta, J.E.; Adamson, B.; Pak, R.A.; Chen, Y.; Fields, A.P.; Park, C.Y.; Corn, J.E.; Kampmann, M.; et al. Compact and highly active next-generation libraries for CRISPR-mediated gene repression and activation. Elife 2016, 5, e19760. [CrossRef]

62. Kweon, J.; Kim, Y. High-throughput genetic screens using CRISPR-Cas9 system. Arch. Pharm. Res. 2018, 41, 875-884. [CrossRef] [PubMed]

63. Sanson, K.R.; Hanna, R.E.; Hegde, M.; Donovan, K.F.; Strand, C.; Sullender, M.E.; Vaimberg, E.W.; Goodale, A.; Root, D.E.; Piccioni, F.; et al. Optimized libraries for CRISPR-Cas9 genetic screens with multiple modalities. Nat. Commun. 2018, 9. [CrossRef] [PubMed]

64. Rahman, M.K.; Rahman, M.S. CRISPRpred: A flexible and efficient tool for sgRNAs on-target activity prediction in CRISPR/Cas9 systems. PLoS ONE 2017, 12, e0181943.

65. Peng, H.; Zheng, Y.; Blumenstein, M.; Tao, D.; Li, J. CRISPR/Cas9 cleavage efficiency regression through boosting algorithms and Markov sequence profiling. Bioinformatics 2018, 34, 3069-3077. [CrossRef]

66. Zhang, D.; Hurst, T.; Duan, D.; Chen, S.-J. Unified energetics analysis unravels SpCas9 cleavage activity for optimal gRNA design. Proc. Natl. Acad. Sci. USA 2019, 116, 8693-8698. [CrossRef]

67. Hwang, G.-H.; Park, J.; Lim, K.; Kim, S.; Yu, J.; Yu, E.; Kim, S.-T.; Eils, R.; Kim, J.-S.; Bae, S. Web-based design and analysis tools for CRISPR base editing. BMC Bioinform. 2018, 19, 542. [CrossRef] [PubMed]

68. Clement, K.; Hsu, J.Y.; Canver, M.C.; Joung, J.K.; Pinello, L. Technologies and Computational Analysis Strategies for CRISPR Applications. Mol. Cell 2020, 79, 11-29. [CrossRef]

69. Shalem, O.; Sanjana, N.E.; Hartenian, E.; Shi, X.; Scott, D.A.; Mikkelsen, T.S.; Heckl, D.; Ebert, B.L.; Root, D.E.; Doench, J.G.; et al. Genome-scale CRISPR-Cas9 knockout screening in human cells. Science 2014, 343, 84-87. [CrossRef]

70. Sanjana, N.E.; Shalem, O.; Zhang, F. Improved vectors and genome-wide libraries for CRISPR screening. Nat. Methods 2014, 11, 783. [CrossRef]

71. Hart, T.; Tong, A.H.Y.; Chan, K.; Van Leeuwen, J.; Seetharaman, A.; Aregger, M.; Chandrashekhar, M.; Hustedt, N.; Seth, S.; Noonan, A.; et al. Evaluation and design of genome-wide CRISPR/SpCas9 knockout screens. G3 Genes Genomes Genet. 2017, 7, 2719-2727. [CrossRef] [PubMed]

72. Liu, J.; Srinivasan, S.; Li, C.-Y.; Ho, I.-L.; Rose, J.; Shaheen, M.; Wang, G.; Yao, W.; Deem, A.; Bristow, C.; et al. Pooled library screening with multiplexed Cpf1 library. Nat. Commun. 2019, 10, 3144. [CrossRef] [PubMed]

73. DeWeirdt, P.C.; Sangree, A.K.; Hanna, R.E.; Sanson, K.R.; Hegde, M.; Strand, C.; Persky, N.S.; Doench, J.G. Genetic screens in isogenic mammalian cell lines without single cell cloning. Nat. Commun. 2020, 11, 1-15. [CrossRef] [PubMed]

74. Xu, P.; Liu, Z.; Liu, Y.; Ma, H.; Xu, Y.; Bao, Y.; Zhu, S.; Cao, Z.; Wu, Z.; Zhou, Z.; et al. Genome-wide interrogation of gene functions through base editor screens empowered by barcoded sgRNAs. Nat. Biotechnol. 2021, 1-11. [CrossRef] [PubMed]

75. Roesch, F.; OhAinle, M.; Emerman, M. A CRISPR screen for factors regulating SAMHD1 degradation identifies IFITMs as potent inhibitors of lentiviral particle delivery. Retrovirology 2018, 15, 26. [CrossRef]

76. Chong, Z.-S.; Ohnishi, S.; Yusa, K.; Wright, G.J. Pooled extracellular receptor-ligand interaction screening using CRISPR activation. Genome Biol. 2018, 19, 1-16. [CrossRef]

77. Słabicki, M.; Kozicka, Z.; Petzold, G.; Li, Y.-D.; Manojkumar, M.; Bunker, R.D.; Donovan, K.A.; Sievers, Q.L.; Koeppel, J.; Suchyta, D.; et al. The CDK inhibitor CR8 acts as a molecular glue degrader that depletes cyclin K. Nature 2020, 585, 293-297. [CrossRef] [PubMed]

78. Chan, K.; Tong, A.H.Y.; Brown, K.R.; Mero, P.; Moffat, J. Pooled CRISPR-Based Genetic Screens in Mammalian Cells. J. Vis. Exp. 2019, 151, e59780. [CrossRef]

79. Wang, T.; Lander, E.S.; Sabatini, D.M. Single guide RNA library design and construction. Cold Spring Harb. Protoc. 2016, 2016, pdb-prot090803. [CrossRef] 
80. Wang, B.; Wang, M.; Zhang, W.; Xiao, T.; Chen, C.-H.; Wu, A.; Wu, F.; Traugh, N.; Wang, X.; Li, Z.; et al. Integrative analysis of pooled CRISPR genetic screens using MAGeCKFlute. Nat. Protoc. 2019, 14, 756-780. [CrossRef]

81. Li, W.; Xu, H.; Xiao, T.; Cong, L.; Love, M.I.; Zhang, F.; Irizarry, R.A.; Liu, J.S.; Brown, M.; Liu, X.S. MAGeCK enables robust identification of essential genes from genome-scale CRISPR/Cas9 knockout screens. Genome. Biol. 2014, 15, 554. [CrossRef]

82. Hart, T.; Moffat, J. BAGEL: A computational framework for identifying essential genes from pooled library screens. BMC Bioinform. 2016, 17, 164. [CrossRef] [PubMed]

83. Meyers, R.M.; Bryan, J.G.; McFarland, J.M.; Weir, B.A.; Sizemore, A.E.; Xu, H. Computational correction of copy number effect improves specificity of CRISPR-Cas9 essentiality screens in cancer cells. Nat. Genet. 2017, 49, 1779-1784. [CrossRef] [PubMed]

84. Daley, T.P.; Lin, Z.; Lin, X.; Liu, Y.; Wong, W.H.; Qi, L.S. CRISPhieRmix: A hierarchical mixture model for CRISPR pooled screens. Genome Biol. 2018, 19, 159. [CrossRef]

85. Allen, F.; Behan, F.; Khodak, A.; Iorio, F.; Yusa, K.; Garnett, M.; Parts, L. JACKS: Joint analysis of CRISPR/Cas9 knockout screens. Genome Res. 2019, 29, 464-471. [CrossRef] [PubMed]

86. Li, W.; Köster, J.; Xu, H.; Chen, C.-H.; Xiao, T.; Liu, J.S.; Brown, M.; Liu, X.S. Quality control, modeling, and visualization of CRISPR screens with MAGeCK-VISPR. Genome Biol. 2015, 16, 1-13. [CrossRef] [PubMed]

87. Joung, J.; Konermann, S.; Gootenberg, J.S.; Abudayyeh, O.O.; Platt, R.J.; Brigham, M.D.; Sanjana, N.E.; Zhang, F. Genome-scale CRISPR-Cas9 knockout and transcriptional activation screening. Nat. Protoc. 2017, 12, 828-863. [CrossRef]

88. Li, Z.; Hajian, C.; Greene, W.C. Identification of unrecognized host factors promoting HIV-1 latency. PLoS Pathog. 2020, 16, e1009055. [CrossRef]

89. Yang, X.; Wang, Y.; Lu, P.; Shen, Y.; Zhao, X.; Zhu, Y.; Jiang, Z.; Yang, H.; Pan, H.; Zhao, L.; et al. PEBP 1 suppresses HIV transcription and induces latency by inactivating MAPK/NF-kB signaling. EMBO Rep. 2020, 21, e49305. [CrossRef]

90. Krasnopolsky, S.; Kuzmina, A.; Taube, R. Genome-wide CRISPR knockout screen identifies ZNF304 as a silencer of HIV transcription that promotes viral latency. PLoS Pathog. 2020, 16, e1008834. [CrossRef]

91. Rathore, A.; Iketani, S.; Wang, P.; Jia, M.; Sahi, V.; Ho, D.D. CRISPR-based gene knockout screens reveal deubiquitinases involved in HIV-1 latency in two Jurkat cell models. Sci. Rep. 2020, 10, 1-14.

92. Jin, S.; Liao, Q.; Chen, J.; Zhang, L.; He, Q.; Zhu, H.; Zhang, X.; Xu, J. TSC1 and DEPDC5 regulate HIV-1 latency through the mTOR signaling pathway. Emerg. Microbes. Infect. 2018, 7, 1-11. [CrossRef] [PubMed]

93. Schneider, W.M.; Luna, J.M.; Hoffmann, H.-H.; Sánchez-Rivera, F.J.; Leal, A.A.; Ashbrook, A.W. Genome-scale identification of SARS-CoV-2 and pan-coronavirus host factor networks. Cell 2021, 184, 120-132. [CrossRef] [PubMed]

94. Wei, J.; Alfajaro, M.M.; DeWeirdt, P.C.; Hanna, R.E.; Lu-Culligan, W.J.; Cai, W.L. Genome-wide CRISPR screens reveal host factors critical for SARS-CoV-2 infection. Cell 2021, 184, 76-91.e13. [CrossRef] [PubMed]

95. Daniloski, Z.; Jordan, T.X.; Wessels, H.-H.; Hoagland, D.A.; Kasela, S.; Legut, M.; Maniatis, S.; Mimitou, E.P.; Lu, L.; Geller, E.; et al. Identification of required host factors for SARS-CoV-2 infection in human cells. Cell 2020. [CrossRef] [PubMed]

96. Wang, R.; Simoneau, C.R.; Kulsuptrakul, J.; Bouhaddou, M.; Travisano, K.A.; Hayashi, J.M.; Carlson-Stevermer, J.; Zengel, J.R.; Richards, C.M.; Fozouni, P.; et al. Genetic screens identify host factors for SARS-CoV-2 and common cold coronaviruses. Cell 2020, 184, 106-119. [CrossRef]

97. Labeau, A.; Simon-Loriere, E.; Hafirassou, M.-L.; Bonnet-Madin, L.; Tessier, S.; Zamborlini, A.; Dupré, T.; Seta, N.; Schwartz, O.; Chaix, M.-L.; et al. A genome-wide CRISPR-Cas9 screen identifies the dolichol-phosphate mannose synthase complex as a host dependency factor for dengue virus infection. J. Virol. 2020, 94, e01751-19. [CrossRef]

98. Lin, D.L.; Cherepanova, N.A.; Bozzacco, L.; MacDonald, M.R.; Gilmore, R.; Tai, A.W. Dengue virus hijacks a noncanonical oxidoreductase function of a cellular oligosaccharyltransferase complex. mBio 2017, 8, e00939-17. [CrossRef]

99. Hoffmann, H.-H.; Schneider, W.M.; Rozen-Gagnon, K.; Miles, L.A.; Schuster, F.; Razooky, B.; Jacobson, E.; Wu, X.; Yi, S.; Rudin, C.M.; et al. TMEM41B is a pan-flavivirus host factor. Cell 2020, 184, 133-148. [CrossRef]

100. Wang, S.; Zhang, Q.; Tiwari, S.K.; Lichinchi, G.; Yau, E.H.; Hui, H.; Li, W.; Furnari, F.; Rana, T.M. Integrin $\alpha v \beta 5$ internalizes Zika virus during neural stem cells infection and provides a promising target for antiviral therapy. Cell Rep. 2020, 30, 969-983. [CrossRef]

101. Dukhovny, A.; Lamkiewicz, K.; Chen, Q.; Fricke, M.; Jabrane-Ferrat, N.; Marz, M.; Lamkiewicz, K.; Chen, Q.; Fricke, M.; Jabrane-Ferrat, N.; et al. A CRISPR Activation Screen Identifies Genes That Protect against Zika Virus Infection. J. Virol. 2019, 93, e00211-19. [CrossRef]

102. Li, Y.; Muffat, J.; Javed, A.O.; Keys, H.R.; Lungjangwa, T.; Bosch, I.; Khan, M.; Virgilio, M.C.; Gehrke, L.; Sabatini, D.M.; et al. Genome-wide CRISPR screen for Zika virus resistance in human neural cells. Proc. Natl. Acad. Sci. USA 2019, 116, 9527-9532. [CrossRef]

103. Das, A.; Barrientos, R.; Shiota, T.; Madigan, V.; Misumi, I.; McKnight, K.L.; Sun, L.; Li, Z.; Meganck, R.M.; Li, Y.; et al. Gangliosides are essential endosomal receptors for quasi-enveloped and naked hepatitis A virus. Nat. Microbiol. 2020, 5, 1069-1078. [CrossRef] [PubMed]

104. Hyrina, A.; Jones, C.; Chen, D.; Clarkson, S.; Cochran, N.; Feucht, P.; Hoffman, G.; Lindeman, A.; Russ, C.; Sigoillot, F.; et al. A genome-wide CRISPR screen identifies ZCCHC14 as a host factor required for hepatitis B surface antigen production. Cell Rep. 2019, 29, 2970-2978. [CrossRef] [PubMed]

105. Guo, R.; Jiang, C.; Zhang, Y.; Govande, A.; Trudeau, S.J.; Chen, F.; Fry, C.J.; Puri, R.; Wolinsky, E. MYC controls the Epstein-Barr virus lytic switch. Mol. Cell 2020, 78, 653-669. [CrossRef] [PubMed] 
106. Wang, C.; Jiang, S.; Zhang, L.; Li, D.; Liang, J.; Narita, Y.; Hou, I.; Zhong, Q.; Gewurz, B.E.; Teng, M.; et al. TAF family proteins and MEF2C are essential for Epstein-Barr virus super-enhancer activity. J. Virol. 2019, 93, e00513-19. [CrossRef] [PubMed]

107. Ma, Y.; Walsh, M.J.; Bernhardt, K.; Ashbaugh, C.W.; Trudeau, S.J.; Ashbaugh, I.Y.; Jiang, S.; Jiang, C.; Zhao, B.; Root, D.E.; et al. CRISPR/Cas9 screens reveal Epstein-Barr virus-transformed B cell Shost dependency factors. Cell Host Microbe. 2017, $21,580-591$. [CrossRef]

108. Xiaofei, E.; Meraner, P.; Lu, P.; Perreira, J.M.; Aker, A.M.; McDougall, W.M.; Zhuge, R.; Chan, G.C.; Gerstein, R.M.; Caposio, P.; et al. OR14I1 is a receptor for the human cytomegalovirus pentameric complex and defines viral epithelial cell tropism. Proc. Natl. Acad. Sci. USA 2019, 116, 7043-7052.

109. Wu, K.; Oberstein, A.; Wang, W.; Shenk, T. Role of PDGF receptor- $\alpha$ during human cytomegalovirus entry into fibroblasts. Proc. Natl. Acad. Sci. USA 2018, 115, E9889-E9898. [CrossRef]

110. Li, B.; Clohisey, S.M.; Chia, B.S.; Wang, B.; Cui, A.; Eisenhaure, T.; Schweitzer, L.D.; Hoover, P.; Parkinson, N.J.; Nachshon, A.; et al. Genome-wide CRISPR screen identifies host dependency factors for influenza A virus infection. Nat. Commun. 2020, 11, 1-18. [CrossRef]

111. Han, J.; Perez, J.T.; Chen, C.; Li, Y.; Benitez, A.; Kandasamy, M.; Lee, Y.; Andrade, J.; tenOever, B.; Manicassamy, B. Genome-wide CRISPR/Cas9 Screen Identifies Host Factors Essential for Influenza Virus Replication. Cell Rep. 2018, 23, 596-607. [CrossRef]

112. Dudek, A.M.; Zabaleta, N.; Zinn, E.; Pillay, S.; Zengel, J.; Porter, C.; Franceshini, J.S.; Estelien, R.; Carette, J.E.; Zhou, G.L.; et al. GPR108 is a highly conserved AAV entry factor. Mol. Ther. 2020, 28, 367-381. [CrossRef] [PubMed]

113. Madigan, V.J.; Tyson, T.O.; Yuziuk, J.A.; Pillai, M.; Moller-Tank, S.; Asokan, A. A CRISPR screen identifies the cell polarity determinant crumbs 3 as an adeno-associated virus restriction factor in hepatocytes. J. Virol. 2019, 93, e00943-19. [CrossRef] [PubMed]

114. Flint, M.; Chatterjee, P.; Lin, D.L.; McMullan, L.K.; Shrivastava-Ranjan, P.; Bergeron, É. A genome-wide CRISPR screen identifies $\mathrm{N}$-acetylglucosamine-1-phosphate transferase as a potential antiviral target for Ebola virus. Nat. Commun. 2019, 10, 1-13. [CrossRef] [PubMed]

115. Diep, J.; Ooi, Y.S.; Wilkinson, A.W.; Peters, C.E.; Foy, E.; Johnson, J.R.; Zengel, J.; Ding, S.; Weng, K.-F.; Laufman, O.; et al. Enterovirus pathogenesis requires the host methyltransferase SETD3. Nat. Microbiol. 2019, 4, 2523-2537. [CrossRef] [PubMed]

116. Liu, T.; Li, J.; Liu, Y.; Qu, Y.; Li, A.; Li, C.; Zhang, Q.; Wu, W.; Li, J.; Liu, Y.; et al. SNX11 identified as an essential host factor for SFTS virus infection by CRISPR knockout screening. Virol. Sin. 2019, 34, 508-520. [CrossRef] [PubMed]

117. Orchard, R.C.; Sullender, M.E.; Dunlap, B.F.; Balce, D.R.; Doench, J.G.; Virgin, H.W. Identification of antinorovirus genes in human cells using Genome-Wide CRISPR activation screening. J. Virol. 2019, 93, e01324-18. [CrossRef]

118. Richardson, R.B.; Ohlson, M.B.; Eitson, J.L.; Kumar, A.; McDougal, M.B.; Boys, I.N. A CRISPR screen identifies IFI6 as an ER-resident interferon effector that blocks flavivirus replication. Nat. Publ. Group 2018, 3, 1214-1223. [CrossRef]

119. Zhang, R.; Miner, J.J.; Gorman, M.J.; Rausch, K.; Ramage, H.; White, J.P.; Zuiani, A.; Zhang, P.; Fernandez, E.; Zhang, Q.; et al. A CRISPR screen defines a signal peptide processing pathway required by flaviviruses. Nature 2016, 535, 164-168. [CrossRef]

120. Ma, H.; Dang, Y.; Wu, Y.; Jia, G.; Anaya, E.; Zhang, J.; Abraham, S.; Choi, J.-G.; Shi, G.; Qi, L.; et al. A CRISPR-based screen identifies genes essential for West-Nile-virus-induced cell death. Cell Rep. 2015, 12, 673-683. [CrossRef]

121. Zhang, R.; Kim, A.S.; Fox, J.M.; Nair, S.; Basore, K.; Klimstra, W.B.; Rimkunas, R.; Fong, R.H.; Lin, H.; Poddar, S.; et al. Mxra8 is a receptor for multiple arthritogenic alphaviruses. Nature 2018, 557, 570-574. [CrossRef]

122. Ding, S.; Diep, J.; Feng, N.; Ren, L.; Li, B.; Ooi, Y.S.; Wang, X.; Brulois, K.F.; Yasukawa, L.L.; Li, X.; et al. STAG2 deficiency induces interferon responses via cGAS-STING pathway and restricts virus infection. Nat. Commun. 2018, 9, 1-8. [CrossRef]

123. Gordon, D.E.; Jang, G.M.; Bouhaddou, M.; Xu, J.; Obernier, K.; White, K.M.; O’Meara, M.J.; Rezelj, V.V.; Guo, J.Z.; Swaney, D.L.; et al. A SARS-CoV-2 protein interaction map reveals targets for drug repurposing. Nature 2020, 583, 459-468. [CrossRef]

124. Hoffmann, H.-H.; Sánchez-Rivera, F.J.; Schneider, W.M.; Luna, J.M.; Soto-Feliciano, Y.M.; Ashbrook, A.W. Functional interrogation of a SARS-CoV-2 host protein interactome identifies unique and shared coronavirus host factors. Cell Host Microbe. 2021, 29, 267-280. [CrossRef]

125. Yang, S.; Zeng, W.; Zhang, J.; Lu, F.; Chang, J.; Guo, J.-T. Restoration of a functional antiviral immune response to chronic HBV infection by reducing viral antigen load: If not sufficient, is it necessary? Emerg. Microbes. Infect. 2021, 10, 1545-1554. [CrossRef]

126. Matharu, N.; Rattanasopha, S.; Tamura, S.; Maliskova, L.; Wang, Y.; Bernard, A.; Hardin, A.; Echalbar, W.L.; Vaisse, C. CRISPRmediated activation of a promoter or enhancer rescues obesity caused by haploinsufficiency. Science 2019, 363, 246. [CrossRef] [PubMed]

127. Saayman, S.M.; Lazar, D.C.; Scott, T.A.; Hart, J.R.; Takahashi, M.; Burnett, J.C. Potent and Targeted Activation of Latent HIV-1 Using the CRISPR/dCas9 Activator Complex. Mol. Ther. 2016, 24, 488-498. [CrossRef] [PubMed]

128. Ophinni, Y.; Inoue, M.; Kotaki, T.; Kameoka, M. CRISPR/Cas9 system targeting regulatory genes of HIV-1 inhibits viral replication in infected T-cell cultures. Sci. Rep. 2018, 8, 7784. [CrossRef] [PubMed]

129. OhAinle, M.; Helms, L.; Vermeire, J.; Roesch, F.; Humes, D.; Basom, R.; Delrow, J.J.; Overbaugh, J.; Emerman, M. A viruspackageable CRISPR screen identifies host factors mediating interferon inhibition of HIV. Elife 2018, 7, e39823. [CrossRef]

130. Chia, B.S.; Li, B.; Cui, A.; Eisenhaure, T.; Raychowdhury, R.; Lieb, D.; Hacohen, N. Loss of the nuclear protein RTF2 enhances influenza virus replication. J. Virol. 2020, 94, e00319-20. [CrossRef] 